\title{
ISOLATION OF A NEW AMINO ACID, 'GIGARTININE', FROM A RED ALGA, GYMNOGONGRUS FLABELLIFORMIS
}

\author{
Keiji ITO* and Yoshiro HASHIMOTO**
}

(Received Dec. 6, 1965)

On acid hydrolysis, the ethanolic extracts of a red alga, Gymnogongrus flabelliformis, revealed a marked change of the amino acid pattern, characterized by decrease of the apparent arginine peak and appearance of both the $\gamma$-aminobutyric acid and ornithine peaks in ion-exchange chromatography. ${ }^{17}$ The origin of $\gamma$-aminobutyric acid was traced to a new guanidino compound present in the extracts. The substance was isolated, identified as $\gamma$-(guanylureido) butyric acid ${ }^{2)}$ and named 'gongrine' for convenience.

As arginine itself is quite stable under the conditions adopted for acid hydrolysis, the apparent loss in the arginine peak was supposed due to disappearance of some unknown, heat-labile substance which might have masked the arginine peak. On this assumption, the strongly basic amino acids were examined more thoroughly and found to be mainly consisted of a new amino acid resembling to arginine. The amino acid is called gigartinine after the name of order including the species $G$. flabelliformis. As gigartinine flows out almost simultaneously with arginine from a short column of Dowex 50 , it may be easily mistaken for arginine in the routine ion-exchange chromatography of amino acids. In addition, it turns into ornithine on acid hydrolysis like citrulline. The remaining problem on the change of amino acids in acid hydrolysis has been thus fully settled by isolation of gigartinine. In this connection, the postulation of Young and SMITH ${ }^{3)}$ seems to need re-examination, that ornithine in the acid hydrolyzed extracts of a red alga, Chondrus crisps may originate from a peptide containing the ornithine residue.

Gigartinine was efficiently purified by column chromatography using a cation exchange resin, Dowex 50 in ammonium form, and obtained as the characteristic nitrate, hydrochloride and picrate. Elementary analyses on these salts gave an empirical formula $\mathrm{C}_{7} \mathrm{H}_{15} \mathrm{O}_{3} \mathrm{~N}_{5}$. A strong absorption peak at $225 \mathrm{~m} \mu$ and the characteristic orange color in the SAKAGUCHI reaction suggested that gigartinine has a guanylurea moiety in the molecule like gongrine. ${ }^{2)}$ On the other hand, a primary amino group was demonstrated by positive reaction with ninhydrin and by estimation of the Van Slyke nitrogen. Five atoms of nitrogen present in gigartinine were

* Faculty of Fisheries and Animal Husbandry, Hiroshima University, Fukuyama, Hiroshima. (伊藤㤵二, 広息大学水蓄産学部)

** Laboratory of Fisheries Chemistry, Faculty of Agriculture, The Tokyo University, Tokyo. (橋本芳郎, 果京大学唯学部) 
accounted for: four in a guanylurea group and one in an amino group.

Degradation products provided a sufficient basis to postulate the structure. When heated at $120^{\circ} \mathrm{C}$ for fifteen hours in $3 \mathrm{~N}$ hydrochloric acid or distilled water, gigartinine decomposed into carbon dioxide, guanidine (II) and L-ornithine (III). The oxidation products with potassium permanganate were guanylurea (IV) and succinic acid (V) and hydrolysis products with barium hydroxide ornithine (III) and citrulline (VI). All degradation products except carbon dioxide were isolated in appropriate forms and identified by melting point, elementary analysis, paper chromatography and infrared spectrum.

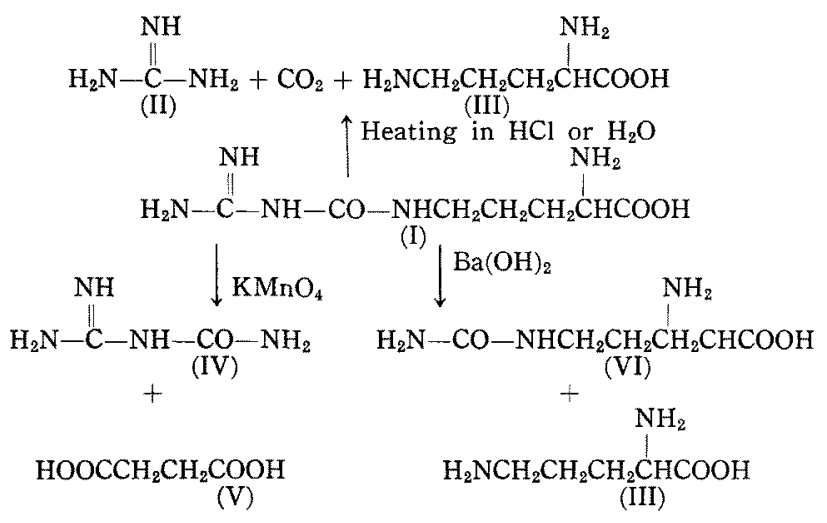

These results led the authors to postulate that gigartinine is $\mathrm{N}^{5}$-(amidinocarbamoyl)L-ornithine or L- $\alpha$-amino- $\delta$-(guanylureido) valeric acid (I).

The present paper deals with isolation, properties and structure of gigartinine. Distribution of both gigartinine and gongrine in algae and the results of re-examination on the extracts of $G$. flabelliformis will be reported in the near future.

\section{Experimental and Results}

\section{Isolation of gigartinine}

Materials of G. flabelliformis and preparation of $75 \%$ ethanolic extracts were the same as described in the previous paper. ${ }^{1}$ The aqueous solution of the extracts obtained from $2 \mathrm{~kg}$ of materials was passed through a column of Dowex $50 \mathrm{X}-8\left(\mathrm{H}^{+}\right.$ form). The adsorbed fraction was then eluted with $2 \mathrm{~N}$ aqueous ammonia until the SAKAGUCHI test indicated the complete elution. After removal of ammonia by evaporation in vacuum, the eluate was left stand for a few days in an ice-box and precipitates of crude gongrine were filtered off. ${ }^{2}$ The mother liquor and washings were again passed through a column of Dowex 50 (ammonium form) to collect the strongly basic substances. The column was washed with water and then eluted with $2 \mathrm{~N}$ aqueous ammonia. The eluate, freed from ammonia, was made up to $300 \mathrm{~m} l$ with water and neutralized to nearly $\mathrm{pH} 5.0$ with $3 \mathrm{~N}$ hydrochloric acid. After being 
decolorized with $3 \mathrm{~g}$ of charcoal, the solution was concentrated to $50 \mathrm{~m} l$. When the colorless solution was allowed to stand in an ice-box overnight, gigartinine hydrochloride crystallized out in fragile needles, which were recrystallized repeatedly from a small amount of hot water and freed from arginine. The yield was $8.8 \mathrm{~g}$.

\section{Properties of gigartinine}

Gigartinine hydrochloride was converted into the nitrate. It was recrystallized from 50 per cent aqueous ethanol into thin plates (Fig. 1), m.p., $197^{\circ} \mathrm{C}$ (under decomposition). Anal. Found: C, 30.23; H, 5.70; N, 29.73; Van Slyke N, 5.22. Calcd. for $\mathrm{C}_{7} \mathrm{H}_{15} \mathrm{O}_{3} \mathrm{~N}_{5} \cdot \mathrm{HNO}_{3}: \quad \mathrm{C}, 30.00 ; \mathrm{H}, 5.76 ; \mathrm{N}, 29.99 ;$ Van Slyke N, $5.00 \% . \quad[\alpha]_{D}^{22}=+$ $7.5^{\circ}(\mathrm{c}=2.0$ in water). The ultraviolet spectrum, estimated on $0.1 \mathrm{~N}$ sodium hydroxide solution, shows a remarkable peak at $225 \mathrm{~m} \mu(\varepsilon=23,000)$. The infrared spectrum is shown in Fig. 2. Gigartinine gives an orange color with SAKAGUCHI's reagent, unlike the orange-red given by arginine, and with ninhydrin the typical violet color, the intensity of which is 0.94 in leucine equivalent. ${ }^{4}$

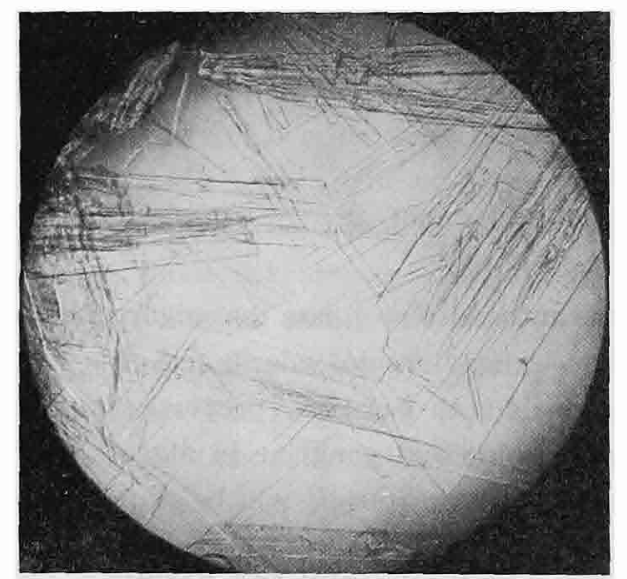

Fig. 1. Crystals of gigartinine nitrate (From $50 \%$ EtOH)

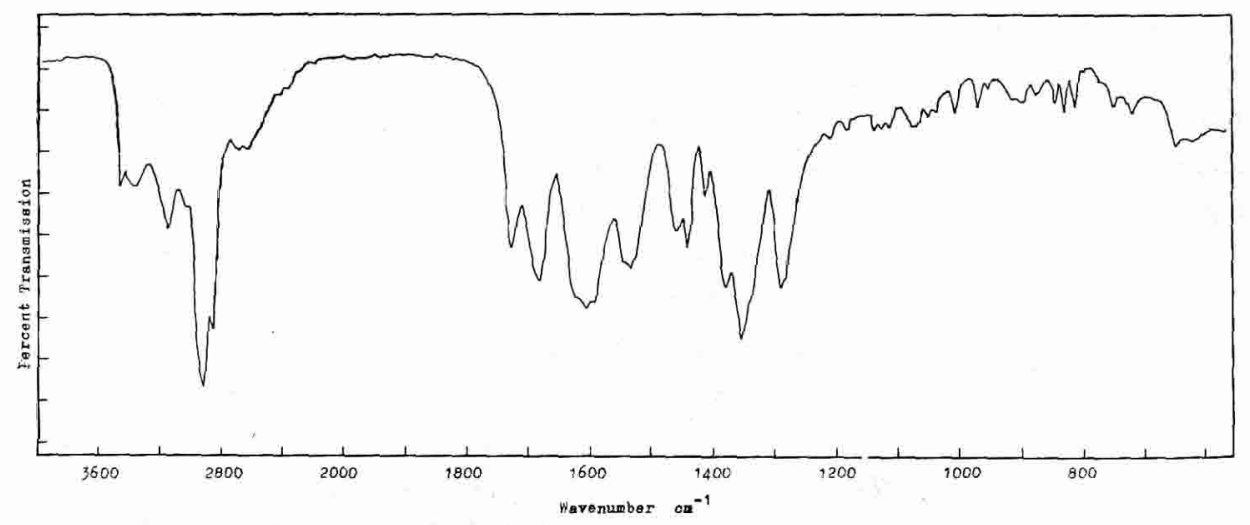

Fig. 2. Infrared spectrum of gigartinine nitrate (in Nujol). 
Gigartinine hydrochloride holds a varying amount of crystalline water, depending on conditions of recrystallization and subsequent desiccation. Even after dried in vacuum on phosphorus pentoxide at $80^{\circ} \mathrm{C}$ for four hours, it still contains a half mole of crystalline water and melts at $98 \sim 100^{\circ} \mathrm{C}$ in a capillary tube. Such a specimen was used for the degradation study described below. Anal. Found: C, 31.89; H, $6.40 ; \mathrm{N}, 26.93 ;$ Van Slyke N, 5.43. Calcd. for $\mathrm{C}_{7} \mathrm{H}_{15} \mathrm{O}_{3} \mathrm{~N}_{5} \cdot \mathrm{HCl} \cdot 1 / 2\left(\mathrm{H}_{2} \mathrm{O}\right): \mathrm{C}, 32.00 ; \mathrm{H}$, $6.52 ; \mathrm{N}, 26.66$; Van Slyke N, 5.33\%. $[\alpha]_{D}^{2 \mathrm{p}}=+17.2^{\circ}(\mathrm{c}=2.0$ in $\mathrm{N} \mathrm{HCl})$. The $R f$ values of gigartinine hydrochloride and its related compounds in paper chromatography using the ascending method and Toyo-roshi No. 50 are given in Table 1.

Table 1. $R f$ values of gigartinine and its related compounds.

\begin{tabular}{l|c|c|c}
\hline \multirow{2}{*}{ Compounds } & \multicolumn{2}{|c|}{ Solvents } \\
\cline { 2 - 3 } & A & B & C \\
\hline Gigartinine $\mathrm{HCl}$ & 0.30 & 0.32 & 0.25 \\
Ornithine $\mathrm{HCl}$ & 0.12 & 0.16 & 0.09 \\
Citrulline & 0.22 & 0.28 & 0.19 \\
Arginine $\mathrm{HCl}$ & 0.25 & 0.24 & 0.16 \\
\hline
\end{tabular}

A, $\mathrm{n} \cdot \mathrm{BuOH} \cdot \mathrm{AcOH} \cdot \mathrm{H}_{2} \mathrm{O}(4: 1: 2)$. B, $\mathrm{n}-\mathrm{BuOH} \cdot$ pyridine $\cdot \mathrm{AcOH} \cdot \mathrm{H}_{2} \mathrm{O}(4: 1: 1: 2)$, C, pyridine iso AmylOH $\cdot \mathrm{ACOH} \cdot \mathrm{H}_{2} \mathrm{O}(8: 4: 1: 4)$.

An attempt to prepare the flavianate of a constant composition was unsuccessful, whereas the characteristic picrate was obtained from water in yellow needles showing no definite melting point. Anal. Found: C, 35.18; H, 4.25; N, 25.24. Calcd. for $\mathrm{C}_{7} \mathrm{H}_{15} \mathrm{O}_{3} \mathrm{~N}_{5} \cdot \mathrm{C}_{6} \mathrm{H}_{3} \mathrm{O}_{7} \mathrm{~N}_{3}: \mathrm{C}, 34.98 ; \mathrm{H}, 4.07 ; \mathrm{N}, 25.11 \%$.

Decomposition of gigartinine at $120^{\circ} \mathrm{C}$ in $3 \mathrm{~N}$ hydrochloric acid or distilled water

Five hundred milligrams of gigartinine hydrochloride was sealed into a tube with $10 \mathrm{ml}$ of $3 \mathrm{~N}$ hydrochloric acid and heated for fifteen hours at $120^{\circ} \mathrm{C}$. The reaction mixture, after removal of the excess acid by evaporation in vacuum, was passed through a column of Dowex $1\left(\mathrm{OH}^{-}\right)$and the column was washed with water. The effluent combined with washings was neutralized with nitric acid and evaporated to dryness under reduced pressure. When the residue was dissolved in a small amount of water and kept overnight in an ice-box, colorless prisms of guanidine nitrate appeared. M.p. and mixed m.p., $212^{\circ} \mathrm{C}$. Yield, $78 \mathrm{mg}(34 \%)$. Anal. Found: C, $10.38 ; \mathrm{H}, 4.90 ; \mathrm{N}, 45.22$. Calcd. for $\mathrm{CH}_{3} \mathrm{~N}_{3} \cdot \mathrm{HNO}_{3}: \mathrm{C}, 9.84 ; \mathrm{H}, 4.95 ; \mathrm{N}, 45.89 \%$. The nitrate was converted to guanidine flavianate and recrystallized from water in yellow prisms, m.p. and mixed m.p., $273^{\circ} \mathrm{C}$. Anal. Found: C, 35.56; H, 3.01; N, 18.58. Calcd. for $\mathrm{CH}_{5} \mathrm{~N}_{3} \cdot \mathrm{C}_{10} \mathrm{H}_{6} \mathrm{O}_{8} \mathrm{~N}_{2} \mathrm{~S}: \mathrm{C}, 35.39 ; \mathrm{H}, 2.97 ; \mathrm{N}, 18.76 \%$.

The column was then washed with $\mathrm{N}$ acetic acid. The eluate was evaporated to syrup, dissolved in a small amount of water, and passed through la column of Dowex $50(20 \times 1.0 \mathrm{~cm}, 200 \sim 400$ mesh, bufferized with $0.1 \mathrm{M}$ citrate buffer, pH 5.0$)$. 
After the column was washed with $30 \mathrm{ml}$ of $0.1 \mathrm{M}$ citrate buffer ( $\mathrm{pH} 5.0$ ), ornithine was eluted with $0.1 \mathrm{M}$ phosphate buffer ( $\mathrm{pH}$ 6.8). The fractions containing ornithine were passed through a column of Dowex $1\left(\mathrm{OH}^{-}\right)$to remove the inorganic salts in effluent. The adsorbed substance was eluted with $\mathrm{N}$ acetic acid, concentrated to dryness in vacuum and dissolved again in $2 \mathrm{~m} l$ of water. The solutions acidified to pH 2.0 3.0 with dilute hydrochloric acid was heated for a few minutes in a boiling water bath, and allowed to stand in an ice-box overnight on addition of $5 \mathrm{ml}$ of absolute ethanol. The crystals of L-ornithine monohydrochloride were obtained. Recrystallized from aqueous ethanol in prisms, m.p. and mixed m.p., $236^{\circ} \mathrm{C}$. Yield, $89 \mathrm{mg}(28 \%) . \quad[\alpha]_{D}^{2 \pi}=+11.7^{\circ} \quad(c=1.8$ in water $)$. This value is in good agreement with that of L-ornithine monohydrochloride listed in Merck Index. ${ }^{5}$ Anal. Found: C, 36.04; H, 7.72; N, 16.47. Calcd. for $\mathrm{C}_{5} \mathrm{H}_{12} \mathrm{O}_{2} \mathrm{~N}_{2} \cdot \mathrm{HCl}: \mathrm{C}, 35.61 ; \mathrm{H}, 7.77 ; \mathrm{N}, 16.61 \%$. The monohydrochloride was converted to ornithine dipicrate, and recrystallized from aqueous ethanol in yellow prisms, m.p. and mixed m.p., $206^{\circ} \mathrm{C}$. Anal. Found C, $34.54 ; \mathrm{H}, 3.28 ; \mathrm{N}, 18.88$. Calcd. for $\mathrm{C}_{5} \mathrm{H}_{12} \mathrm{O}_{2} \mathrm{~N}_{2} \cdot 2\left(\mathrm{C}_{6} \mathrm{H}_{3} \mathrm{O}_{7} \mathrm{~N}_{3}\right): C, 34.58 ; \mathrm{H}, 3.07 ; \mathrm{N}$, $18.98 \%$.

Decomposition of gigartinine hydrochloride in distilled water at $120^{\circ} \mathrm{C}$ for fifteen hours resulted in formation of the same degradation products, guanidine and ornithine, which were identified by paper chromatography. In this experiment, carbon dioxide formed was determined by the microdiffusional method and the yield was $68 \%$.

Oxidation of gigartinine with potassium permanganate

Five hundred milligrams of gigartinine hydrochloride was treated with potassium permanganate in the same way as gongrine, ${ }^{2)}$ and the same oxidation products, succinic acid and guanylurea, were obtained.

Succinic acid was recrystallized from hot water in prisms, m.p. and mixed m.p., $185^{\circ} \mathrm{C}$. Yield, $53 \mathrm{mg}(24 \%)$. Anal. Found: C, 40.81; H, 4.91. Calcd. for $\mathrm{C}_{4} \mathrm{H}_{6} \mathrm{O}_{4}: \mathrm{C}$, $40.68 ; \mathrm{H}, 5.12 \%$.

Guanylurea sulfate was obtained in needles from aqueous ethanol, m.p. and mixed m.p., $196^{\circ} \mathrm{C}$. Yield, $94 \mathrm{mg}(29 \%)$. Anal. Found: C, 15.77; H, 4.87; N, 36.80. Calcd. for $\mathrm{C}_{2} \mathrm{H}_{6} \mathrm{ON}_{4} \cdot 1 / 2\left(\mathrm{H}_{2} \mathrm{SO}_{4}\right): \mathrm{C}, 15.89 ; \mathrm{H}, 4.67 ; \mathrm{N}, 37.07 \%$.

\section{Hydrolysis of gigartinine with barium hydroxide}

Five hundred milligrams of gigartinine hydrochloride was boiled in $30 \mathrm{ml}$ of $5 \%$ baryta solution under reflux for ten hours. After cooling, the mixture was neutralized with sulfuric acid and barium sulfate was filtered off. The filtrate and washings were concentrated to nearly $2 \mathrm{~m} l$ in vacuum, and fractionated by means of a column of Dowex $50(20 \times 1.0 \mathrm{~cm}, 200 \sim 400$ mesh, bufferized with $0.1 \mathrm{M}$ citrate buffer $)$ into ornithine, citrulline and unchanged gigartinine.

Citrulline on the resin was eluted with $40 \mathrm{ml}$ of $0.1 \mathrm{M}$ citrate buffer ( $\mathrm{pH} \mathrm{5.0)} \mathrm{and}$ the eluate was again treated with a column of Dowex $50\left(\mathrm{H}^{+}\right)$to remove citric acid. 
The resulting solution, after removal of ammonia, was concentrated to dryness in vacuum, dissolved again in a few $\mathrm{m} l$ of water and added absolute ethanol until the solution became opalescent. When kept in an ice-box, citrulline appeared as colorless plates. Recrystallized from aqueous ethanol, m.p., $222^{\circ} \mathrm{C}$. Yield, $59 \mathrm{mg}(18 \%)$. Anal. Found: C, 41.09; H, 7.40; N, 23.71. Calcd for $\mathrm{C}_{6} \mathrm{H}_{13} \mathrm{O}_{3} \mathrm{~N}_{3}: \mathrm{C}, 41.13 ; \mathrm{H}, 7.48$; N, $23.99 \%$.

Ornithine remaining on the resin was eluted with $120 \mathrm{ml}$ of $0.1 \mathrm{M}$ phosphate buffer ( $\mathrm{pH}$ 6.8). The eluate was again put on a column of Dowex $1\left(\mathrm{OH}^{-}\right)$to remove inorganic salts. Elution from the column was carried out with $\mathrm{N}$ acetic acid. The eluate, freed from acetic acid, was dissolved in $2 \mathrm{~m} l$ of water and treated with excess picric acid in ethanol. The precipitates of ornithine dipicrate were recrystallized from aqueous ethanol in prisms, m.p., $206^{\circ} \mathrm{C}$. Yield, $270 \mathrm{mg}(24 \%)$. Anal. Found: C, 34.57; $\mathrm{H}, 3.31 ; \mathrm{N}, 18.58$. Calcd. for $\mathrm{C}_{5} \mathrm{H}_{12} \mathrm{O}_{2} \mathrm{~N}_{2} \cdot 2\left(\mathrm{C}_{6} \mathrm{H}_{3} \mathrm{O}_{7} \mathrm{~N}_{3}\right): \mathrm{C}, 34.58 ; \mathrm{H}, 3.07 ; \mathrm{N}$, $18.98 \%$.

\section{Summary}

A new amino acid 'gigartinine' was isolated from the red alga, Gymnogongrus flabelliformis, by means of ion-exchange resin, Dowex 50 (ammonium form). From the analytical data, color reactions, decomposition products and other evidences, it was identified as $\mathrm{N}^{5}$-(amidinocarbamoyl)-L-ornithine or $\mathrm{L}$ - $\alpha$-amino- $\hat{\boldsymbol{o}}$-(guanylureido) valeric acid.

\section{References}

1) K. ITо: This Bull., 31, 307 (1965).

2) K. Iтo and Y. Нaseimoto: Agr, Biol. Chem., 29, 832 (1965).

3) E. G. Young and D. G. Smith: J. Biol. Chem., 233, 406 (1958).

4) S. MOoRe and W. H. Stein: J. Biol. Chem., 176, 367 (1948).

5) The Merck Index, 7th ed., p. 758 (1960). 